\title{
Commemoration, Conservation, and Commodification: Representing the Past in Present-Day Tokyo
}

\author{
Paul WALEY \\ University of Leeds, $U$. $K$.
}

\begin{abstract}
Various commentators have observed that Tokyo is missing the grand monuments that are a feature of many other large capital cities. Indeed, it could even be said that the city lacks a physical sense of its own history. This paper examines these propositions and lays out a number of reasons why this may be so. I argue here that the treatment of the past in contemporary Tokyo can be understood through the lens of commemoration, conservation, and commodification. While Tokyo may lack grand memorials and significant conservation areas of historical importance, I argue both that the city contains smaller, more improvised monuments and that consumption objects and indeed re $^{-}$created streetscapes furnish a sense of the past in today's city. I suggest at the same time that within Tokyo there has been a concentration on bringing in elements of a Western urbanism considered more modern or, recently, more exotic, and that the past has tended to be consigned to places outside Tokyo. There is in sum little space in Tokyo's ever-changing landscape for a physical representation of the past. These claims about the contemporary city are placed in the context of geographical writing on memorialisation and related themes such as heritage in a broader Asian and European context.
\end{abstract}

Key words: Tokyo, memory, monument, place, the past, urban landscapes

\section{Introduction: The Place of Memory in the City}

When the author Akutagawa Ryūnosuke returned not long after the Great Kantō Earthquake to the part of Tokyo in which he had grown up, he included in his description of the desolation he found the following lines: "I recalled that the Fujimi ferry had surely been somewhere around here. But nowhere could I see anything resembling the hut at its landing stage. I decided to ask a man of about thirty who was peeling potatoes there at the side of the road whether it still existed. He had, however, not heard of the Fujimi ferry, let alone its landing stage" (quoted in Waley 2003, 221). This sense of a city that has no memory of the past has pervaded much writing about Tokyo. Tokyo's landscape is always changing, it seems, with scarcely a thought to the past. But is it really the case that the ephemeral nature of Tokyo's landscape has really led to a lack of visual reminders of the past? Is the urban landscape so plastic and the collective memory so malleable as to mean that the past is not remembered anywhere in the physical environment?

I argue in this paper that memory takes little physical shape in the cities of Japan, and especially in Tokyo. The past is not physically present in Tokyo, and this has consequences for the way life is lived there. But nor is it absent either. It is to be found principally in commodified 
form, in objects for display in museums, in products for sale in shops, in consumable items such as food and drink, in films and television dramas, and even, extending the notion of commodification into the abstract realm, in place names with their historical associations such as Asakusa and Shitamachi. It is also to be found, and here we venture beyond the compass of this essay, in social practices like festivals as well as informal associational groupings. And most importantly, it is to be found outside Tokyo, in Kyoto, in Meiji Mura, in Kamakura and Nikkō, in the countryside, in the furusato, or (imagined) hometown.

The present essay picks up on the approach adopted by contributors to Mirror of Modernity: Invented Traditions of Modern Japan (Vlastos 1998) and the general argument advanced in that book that our understanding of the past is always undergoing a process of re-invention according to the needs and the ideologies of the present, arguments recently reinforced in the edited volume Making Japanese Heritage (Brumann and Cox 2011). As David Lowenthal has so epigrammatically suggested, "the past is a foreign country" $(1985,4)$. To enter this country and visit the past, we use our memory, but our memories of the past are acts of imagination. Absurdly obvious though the proposition may be, the problem with the past is that it no longer exists. It follows that our memories (of the past) exist in the present. Because memory is in the present, it reflects the present. Memory creates history. Indeed Maurice Halbwachs has gone so far as to argue, in the words of Lewis Coser, that, "the past is a social construction mainly, if not wholly, shaped by the concerns of the present" (Coser 1992, 25). Philippe Nora reflects this sentiment $(1989,7)$ : "Memory is a perpetually actual phenomenon." Picking up on the ideas of Halbwachs, Karen Till writes that, "For Halbwachs, personal memory is not 'stored' in the subconscious, as Sigmund Freud suggested, but is always constructed and located in the social environments of the present" $(2003,290)$. If memory resides in the present, its business is with the past, with the act of remembering. Our projections into the past through the act of recollection help us define our present identity, or, in the words of David Lowenthal, "Remembering the past is crucial for our sense of identity ... : to know what we were confirms what we are" $(1985,197)$. It is through a shared understanding of a past, a shared past, that collective identities are forged, even as individual identities are in flux as we make sense and incorporate our own personal histories.

Nora refers to memory as being "open to the dialectic of remembering and forgetting" (Nora $1989,8)$, reminding us of the possibilities of forgetting. But as Kusno has written $(2004,2378)$ : "What is ... important is not what has been forgotten and remembered, but how and why certain memories are institutionalised, transformed and invested with particular meaning for the regulation of the public." Forgetting too can be an institutionalised act, as John Dower wrote, "Remembering Hiroshima and Nagasaki became a way of forgetting Nanjing ..." (quoted in Karacas 2101, 528).

Once memories are institutionalised, they cease to be personal (or autobiographical, to use Halbwachs' terminology) and have become collective (or social) memories - Halbwachs refers to historical memory. The collective memory is inevitably political and therefore also ideological (Cartier 2002), likely to be shaped by the state. Till talks about public memory as being negotiated (1999). Like the social memory, fixed and institutionalised, traditions - supremely ideological as they are - stand caught in a "disjuncture between the rhetorical posture of invariance $\cdots$ and their actual historicity" (Vlastos 1998, 7). Like memories, traditions are forged in the furnace of contemporary debate. Traditions are like a collective manifestation of collective memory. Like memories, traditions can take the form of ritual and performance. "Inspired by Hiroshima and 
Nagasaki," Karen Till writes, "scholars from many disciplines now pay attention to the material landscapes and cultural performances of social memory" (Till 2003, 291). But memories, unlike traditions, can be - and often are - incorporated into monuments and attached to specific places. In a study of memory, emotion and place, Owain Jones argues that memory is "clearly bound up with processes of place and emotional attachments to place" $(2005,213)$.

The relationship between memory and place materialises, or so I argue in this paper, in three forms - commemoration, conservation, and commodification. Commemoration involves the symbolic representation of collective memory in a physical structure, or in an event, or both. Conservation is the preservation of physical structures, sometimes including their surroundings, in something approximating to their "original form." Commodification is here the conversion of objects that come from past times or are made to resemble past artefacts into products to be exhibited in museums or sold in markets. Stated thus, the picture is a bit too simple. There is much overlap. To give one obvious example, a display of commodified memories from the past might be housed in a museum occupying a house that has been preserved from development. And I shall argue here that commodification can in some circumstances be extended beyond a physical product and include a larger entity such as a whole district.

One of the aims of this paper is to insert Tokyo into discussions about ways in which the past can be thought of as being "present" in the urban landscape. Tokyo is important because it is Japan's capital city - and the differences with Kyoto, the historical capital, whose history is clearly marked on the urban terrain, are clear. I am working from the often-observed supposition that there is very little in today's capital city that marks Tokyo out as a monumental capital city (apart perhaps from its size), and very little that has been preserved of the city's historic buildings. Contrast Rome, where the many historical layers - classical, medieval, renaissance, baroque, Risorgimento, fascist - are all clearly visible. But in Rome readings of the past have always been and remain equally contested as in Tokyo (Atkinson and Cosgrove 1998; Bosworth 2011).

The rest of this paper examines the place of the past in the urban landscape of Tokyo through the three devices set out above, but the paper starts with a discussion of the role of commemoration, conservation, and commodification in a wider Asian and European context as part of my attempt to situate Tokyo within a regional and global setting. In discussing each of these forms of representation of the past in the contemporary city, I will draw attention to the leading roles played by the state, in the case of commemoration, by civil society, in the case of conservation, and by capital, for commodification. This is not to preclude activity and significant involvement from other social forces, for in each case there is a mixture of many interests involved, but rather to describe points of emphasis. Indeed, as Karen Till (2003, 295) writes, "Different political parties, factions, and 'publics' negotiate understandings of the past (and of social identity) at multiple scales through place."

\section{Treating the Past in Asian and European Cities}

Commemoration suggests the pooling of personal memories or perhaps, conversely, an attempt to disperse into the personal level an official, political memory. Commemoration, the bringing together of memories, can occur through the medium of events as well as through the erection of monuments. It may occur at the site of a specific event, or series of events, or may involve the construction of a monument to commemorate an event that occurred elsewhere. But most commonly, there is a combination of a site of special significance with a monument 
constructed to honour the memory that the site incorporates. These are indeed lieux de mémoire (Nora 1989). Commemoration can vary in scale, from a single standing monument to a building, or even in some circumstances, a whole townscape. It may be a heroic individual who is being commemorated, as in the case of the Irish heroes whose statues on the streets of Dublin are discussed by Nuala Johnson (1995), or a victory in battle. Or it may be the victims of a disaster or of persecution more generally. Sometimes it is principally the event itself that is being commemorated.

Many studies of memory and its transferral into monument have been occasioned by events surrounding the end of the Cold War, which involved the rewriting and institutionalisation of a new understanding of European history. Studies by Andrew Charlesworth (1994) on Auschwitz and Maoz Azaryahu (2003) on the Buchenwald concentration camp expose the manipulation of memory through the changing historical narratives of victimhood during and after the Second World War. Martin Purvis and David Atkinson (2009) report on the contentious events surrounding the commemoration of mass killings in and around Trieste in the Second World War. The uncertainties and conflicts that accompanied political change in Central and Eastern Europe throughout the twentieth century led to the frequent resort to a different form of commemoration, the use of street-names to commemorate groups of people or individuals of symbolic, often 'national' importance. In Taiwan, the Nationalist Party (KMT) renamed many of the streets of Taipei literally to stamp the geography of southern mainland China onto their new capital city (Leitner and Kang 1999). In many parts of the world, including South East Asia, national independence has lent itself to state-led projects of commemoration in monuments. In Jakarta, the national monument, Monas, serves as an official celebration of liberation from colonial rule, but it has also been used as part of a programme of representing Jakarta as incarnation of the modern nation of Indonesia (Kusno 2004).

In all the above examples of commemoration through memorialisation, the state has played the leading role, but it has certainly not been the only actor, in a process that has in many cases been the subject of contestation. The state itself is fragmented territorially, and divided in terms of the views and culture of those who work for it. But the state's frequent attempts to establish an "official" commemoration are inherently conflictual because the currency of commemoration lies in collective memory, with many parties involved (Till 2003, 295). Because it has most at stake and is best placed to marshal the necessary resources, the state normally takes on the task of defining the collective memory and manipulating into a monument. Above all, the state seeks to commemorate state-building "moments" in monuments and events in an attempt thereby to bring people together and create obedient citizens.

Where commemoration tends to involve the manipulation of memory around a monument or event, conservation entails the preservation and representation of the past. Unlike commemoration, conservation is unlikely to involve ceremonies or a sense of marking a specific event or the heroic activities of an individual or group of people. Unlike the commodification of the past, conservation does not have to involve the attaching of value to a product, although in fact it often does, not least as a result of the power of tourism. Conservation is closely linked to, indeed is driven by, a sense of heritage, of tangible (and intangible) evidence of the past transmitted down into the present. Heritage, among other things, is the management of collective memory (Chang and Yeoh 1999), while conservation is the mechanism that makes heritage visible. Conservation tends to operate according to guidelines set by the state through a planning framework, but it is often civil society that is the driving force behind conservation projects. 
Conservation has almost as much potential for conflict as does commemoration. In Taiwan, the preservation of old buildings is an important means of expressing a sense of Taiwanese - as opposed to mainland Chinese - identity and culture. A recent emphasis on the preservation and revalidation of historical buildings has occurred as part of a policy of underscoring Taiwan's difference from mainland China (Tan and Waley 2006; Simon 2003). In many cities of East Asia, from Seoul to Jakarta (but, significantly, not in Tokyo) preserving the past involves some sort of compromise with colonial history (Logan 2002). In Seoul, the colonial past has been dismantled where possible, but in Singapore, which was after all a colonial foundation, it forms a defining framework for national heritage. In the case of Jakarta, Abidin Kusno (2004) has argued that current administrations are attempting to present the sense of order they identify in colonial urbanism as a vision of how the city should be today. In Singapore, a "heritage landscape" has been created, "provid [ing] the nation with a sense of historical continuity" (Kong and Yeoh 2003, 135). Ethnic parcels of the past have been fenced off and preserved, and as a result, some would argue, divorced from ambient living cultures (Chang and Yeoh 1999).

Heritage and tourism are linked to conservation efforts, but it is in the commodification of the past that, arguably, they play their greatest role. Commodification occurs for the purposes of extraction of exchange value. It enables the consumption of memory, including its ingestion as food or drink, and can involve the packaging of memories into celebrations, music - or entire landscapes. The conversion of the south-western Chinese town of Lijiang into a centre of tourism has, according to Emily Chao (2003), led to the commodification of its landscape in a number of respects. It has changed the way that people live there, and the places they inhabit; as tourist facilities have invaded the older centre, the city's inhabitants have been pushed out into new suburbs $(2003,79)$.

In the historic centres of Europe, the commodification process has been taken a long way. The French novelist Benoît Duteurtre (2011) describes the process of "manufacturing" (and therefore also commodifying) Paris. He details the measures that have been undertaken to promote a picture of Paris that conforms to the tourist vision of the city, as represented in tourist brochures and the like. Elsewhere, in Europe and beyond, "glorious" urban histories are wrapped up, bottled, translated into images and sold in a myriad products appearing in shops all over the city. In this way, the past is commodified and sold on the marketplace of national and international tourism. Commodification of the urban landscape is an ineluctable feature of the contemporary urban world.

\section{Commemorating the Past in Contemporary Tokyo}

This paper now moves onto a consideration of how these three different means of recalling and representing the past figure in the landscape of contemporary Tokyo. How and where is its past commemorated, conserved and commodified in Tokyo today? In discussing these questions in the following sections, I draw on the work of a number of writers and my own research in this area.

If we accept the premise that Tokyo has fewer commemorative structures than other large capital cities, we have to ask ourselves why. One reason hinges on state attitudes towards historical events. Just as the Tokugawa shogunate saw no reason to re-build Edo castle's main tower after it had been destroyed by fire in 1657, so the resistance in Edo to the Meiji troops in 1868 was short-lived (even if the confusion was great), and there was little sense of a need for 
triumphal architecture to commemorate the victory over shogunal loyalists (Steele 1990). Above all perhaps, the embrace of a Western-facing modernity and the construction of a new imperial capital meant there was neither the appetite nor the time for the past. The imperative was to transform Tokyo into an Imperial Capital (teito) with fine buildings, wide boulevards, and a cityscape that might rival that of European capitals. However, the insufficient state of the national purse eventually ruled that out (Fujimori 1982). Edo and Tokyo shared the same geographical space, but Edo was so tightly reflective of the political system of the shogunate that once the system fell, the old city went with it. A lingering nostalgia remained among a few former Tokugawa officials, but this failed to find political shape, and Tokugawa apologists took umbrage in satire, holding onto their personal maps of the shogun's city to reaffirm their own memories (Maeda 1982).

Another crucial reason for the lack of commemorative structures in Tokyo is the tragic outcome of the Pacific War, tragic not least for Tokyo and its inhabitants. But consensus has never been reached on the political dimensions of that tragedy. And nowhere is this lack of consensus more sharply etched on the urban terrain than at Yasukuni Shrine, where the souls of Japanese who died in uniform are commemorated, including figures indicted for war crimes. There is no need here to rehearse the controversy surrounding the shrine and the commemorative ceremonies held each year on 14 August (Takahashi 2006, 158; Seaton 2007). But for the rest of the year, even if some of the debates simmer on, the shrine buildings themselves, walled off from the city streets, return to obscurity (Ben-Ari 2005). They are not imposing buildings, and they do not force themselves on the attention of passer-by. By no stretch of the imagination could they be seen as a Japanese equivalent to the Arlington Cemetery - or to Les Invalides in Paris. This is a restful shrine compound, not unattractive, especially in spring when the cherry trees are in blossom, but not at all bombastic or portentous. Even more discreet than Yasukuni Shrine is the nearby monument to the memory of all Japanese who died in the war, which lies hidden away in a discreet corner opposite the Imperial Palace - anything but monumental (White 2011).

That there is a lack of monuments and commemorative structures in Tokyo can be attributed in part to the destructive power of the two great disasters that overtook the city during the course of the twentieth century, the Great Kantō Earthquake of 1923 and the air raids of 1944 and 1945, and in particular the devastating raid of the night of 9 March 1945. And yet, conversely, one might have expected an imposing memorial to those who died in these two events. One looks in vain. The hall built to commemorate those who perished in the earthquake is located on the site of the single worst catastrophe within this catastrophic event. It was designed by the architect Itō Chūta, but location and ponderousness of design have relegated the building to relative obscurity. In recent years, the hall to the victims of the earthquake has shared its extremely cramped grounds with a memorial to those who died in the air raids. The controversy surrounding the construction of this memorial has been discussed in some detail by Cary Karacas (2010). In his account, Karacas relates how plans to build a separate peace museum that both commemorated the victims of the air raids and put the attacks in the wider context of Japan's role in the Second World War were defeated as a result both of opposition from the nationalist political right and of budgetary pressures.

As I suggested earlier, only the state has the resources, the stamina, the imperative need to stamp a view of history onto the landscape. But it would be misleading to suggest that the Japanese state has been completely disinterested in commemorations of the past in its capital 
city, just that state-sponsored commemoration is not a prominent feature of the landscape as it is in so many other large capital cities. State-sponsored commemoration in Tokyo tends to be downplayed and often overlooked, but it is not entirely absent. There is, for example, the safe but important figure of Ōta Dōkan, founder of the first significant settlement on the banks of the bay, whose statue moved with the City Hall from Yūrakuchō to Shinjuku. Then there is the statue of Saigō Takamori, the somewhat ambivalent figure who led the 1877 Satsuma Rebellion. The site of his statue on Ueno hill was once suitably imposing, but Ueno is no longer central in the city, and the statue looks rather forlorn.

As James White points out, Tokyo has few monumental statues (2011,37). This is in large part due to the lack of ceremonial spaces in the city, the only such space today being the concourse in front of the Imperial Palace (Kōkyo Gaien) - but the equestrian statue that stands there celebrates a medieval warrior hero who bears no connection with the city. In the Meiji and Taishō eras, various temporary monuments appeared, celebrating and formalizing the link between the imperial capital and expanding empire. These included triumphal arches - in Hibiya Park, for example - to commemorate the victory in war with Russia. The passing of the Meiji emperor was marked by the construction of a shrine to his memory in expansive grounds, part of a wider remodelling of Tokyo's western suburbs.

Commemoration involves events as well as monuments, and while this paper is focussed on monuments because they represent the past in contemporary urban landscapes, one should not ignore the fact that the city's history has been celebrated at various commemorative events. Makiko Iwatake has traced the several celebrations that have occurred to mark notable city anniversaries. She concludes her study bv arguing that "All the anniversaries of different temporal orders share one thing in common, that Tokyo should find its place among these [world] cities" (2003).

In fact, many of the commemorative structures that are most prominent and closest to the daily lives of the people of Tokyo are the manifestations of improvised collective memory built up around personal experience. The classic case is that of Hachikō, the statue to a dog waiting patiently for his master outside Shibuya Station (Waley 1991, 231). This memorial to canine fidelity belongs to the everyday life of Tokyoites, both because it tells a story that reflects a poignant chapter in an everyday history and because it is probably the most popular meeting point in the city and close therefore to the pleasures and pains of everyday social life.

Other iconic places in the popular collective memory include Kaminarimon, the gate guarding the entrance to the Asakusa Kannon temple, with its two Niō guardian deities. Around the city, but particularly in the east and northeast of Tokyo, temples and shrines like the Eitaiji and Tomioka Hachimangū in Fukagawa whose buildings are not in themselves old nevertheless give the map of the city meaning, especially for older people, and provide a sort of network of points of commemoration across the city. The linkage between these points is central to certain rites, of an at least partly commemorative nature, such as the pilgrimage routes to the Seven Deities of Good Fortune (Shichi Fukujin) that are found in various parts of the city such as Mukōjima and Yanaka and that are still observed and visited, generally in a spirit of urban exploration (Waley 1996 ; 2010). It could even be said that, ironically perhaps, in a country where since the end of the last war the state has been constitutionally detached from religious bodies, the main commemorative edifices are religious. But that would perhaps be to misapprehend the spirit in which these buildings and their compounds are appreciated, which tends to be generally recreational blending in with a sense of ritual. 
There is one other form of commemorative re-living of the past that occurs in Tokyo, as it does in other Japanese cities, and that is what one might call participatory commemoration (Steelman 2011). For two or three decades, Japanese cities have been the scene of community planning, or machi-zukuri, projects in which local residents engage in activities designed to create an understanding of local history. Many of these exercises in collective memory aim to preserve and celebrate local memories (Nunokawa 2007). Some are organised explicitly by local government; others, as a form of opposition to development plans, by local citizens; still others emerge out of a joint initiative by local government and local elites (Waley 2005a). In the 1980s, while living in Arakawa ward, northeast Tokyo, I took part in a machi-zukuri project in the ward. Initiated by local ward officials, the aim of the project was, through a series of meetings with community leaders over a period of a year, to compile and publish a report and make a film that could be used to stimulate interest and pride in the history and culture of a part of Tokyo that was seen as suffering from low self-esteem. While it should be stressed that by no means all machi-zukuri projects have this set of aims, they are sufficiently numerous throughout urban Japan to suggest that they represent an important form of commemoration. They serve to identify and articulate individual memories and pool them together to form a powerful collective memory based around urban sites.

My overall argument in this section, however, has been that there is a significant lack of commemorative space in Tokyo. This is the result in part, I have argued, of equivocal feelings for Tokugawa Edo and a lack of consensus over Japan's role in the Second World War. But it is also the result, as James White $(2011,137)$ suggests, of a search for urban models of modernity outside Japan, in the West and in Western cities. Whole districts such as Ginza were built in order to re -create Western (and often specifically European) urbanism in Tokyo. Individual buildings such as the Rokumeikan and features such as Hibiya Park were designed specifically to implant a Western sense of urban living in Japan's capital (Waley 2005b). This contrasts in a fascinating way with the spirit of urbanism in Europe, which has relied for so long on reversions to and reinventions of classical patterns. One thinks for example of baroque Rome, Paris and Berlin, with their echoes of an imagined glorious classical urbanism, or individual buildings from St Peter's in Rome to the British Museum, designed as re-interpretations of classical architectural concepts and motifs. Nevertheless, one must set against this the survival of spaces of continuity, temples, shrines and parks that provide memories of the past (Jinnai 1985). The buildings themselves may not be more than half a century old, although they are often built in traditional style, but the space they occupy tends to be a constant in the geography of the city. This helps to form a sort of collective commemorative map of the city, reinforced by the inevitably more disparate efforts of local government and civil society.

\section{Conserving the Past in Buildings and Landscapes}

Civil society and the state are both involved in conservation activities in Tokyo. The state generally plays a withdrawn role, setting the ground rules at a national level. Civil society for its part is plural and diverse and, as we will see below, liable to approach conservation projects from different perspectives, with significant interests often promoting development over conservation.

There is only an attenuated sense of state responsibility for conservation, expressed in a legislative framework anchored in the Law for the Protection of Cultural Properties of 1950. That is not to say that the state has been absent from conservation efforts. Perhaps the most 
important measure of the post-war decades was the introduction of Important Preservation Districts for Groups of Historic Buildings (IPDs) in 1975 (Hohn 1997). The impact of this measure has been significant, but not unproblematic, with excessive bureaucracy and unmanageably large tourist influxes causing complications. The state's conservation policies have emphasised equally people, crafts, intangible traditions, while state disassociation from religion after the war means that conservation efforts for temples and shrines are not within the purview of the state.

As I suggested earlier, Tokyo has since the early Meiji years been seen as the most fertile bed for the introduction of modernity into Japanese cities. There has been little attempt to preserve buildings or streetscapes in the Japanese capital. It is true that there have been important continuities in the use of land; one thinks, for example, of the first five parks established in Tokyo in the early Meiji years, each of them on land that had held some significance under the shogunate (Waley 2005). Nevertheless, even such a revered site as the Mukōjima embankment was largely left to its own devices, and while a few historians and cultural figures fought for its conservation, their ideas were never realised (Waley 2010).

My argument here is that conservation efforts, especially in Tokyo, have come almost exclusively from civil society. Yanaka, in the northwest corner of Taitō Ward, presents itself as an example (for a longer discussion, see Waley 2012). This is one of the very few districts in inner and central Tokyo that offers a suggestion of a past Tokyo (the vagueness inherent in the word 'past' is intentional), with its many temples, narrow lanes and predominantly two-storey housing. The pressures to $\mathrm{re}^{-}$structure and develop Yanaka have been considerable, and a number of large condominiums have been built along main roads. But this process has been successfully impeded through the activities of a number of local community groups. When compared with apparently similar groups in European cities, the activities of groups in Yanaka have been noticeably nonconfrontational. There is a level of acceptance that property owners have a much stronger hand to play. The strategy therefore has been to talk to property owners and try to persuade them to refurbish existing buildings, by using student tenants, for example, to do the work, or to re-build in harmony with the surroundings. This is all within a context of longstanding and varied community activity in the Yanaka area. This is exemplified by the Yanesen local magazine, which for many years provided a focus for diverse and imaginative community activities.

Leaving conservation efforts to civil society has unpredictable consequences, as we can see in the struggle over what was to become of Shinobazu-no-ike, the lake that lies just south of Yanaka. The plan to build a car park under the lake was promoted by two civil society groups, the Ueno Tourist Association (Ueno Kankō Renmei) and Ueno Shopkeepers Association (Ueno Shōtenkai). The official plan was actually drafted in the offices of the Taitō Ward Office, and was announced to some considerable surprise in the Yomiuri newspaper in 1986 (Shimizu 1998, 9). The size of the planned car park and the fact that the lake was to have been drained to enable its construction drew strong criticism, and this led to the drafting of a more modest plan with a smaller car park (Ogawa 1990; Mori 2003). The critics, having mobilised considerable support among influential residents of Yanaka (Miyauchi 1990), were not impressed, believing both that the construction of the car park would damage aquatic life in the lake and that a larger car park was not in any case needed. In the end (and somewhat unusually for a movement opposing development), they won on all counts, and plans for the car park under Shinobazu-no-ike were dropped in 1997.

The struggle over the car park under the lake shows how groups can pull in different directions. Civil society is not always the best guardian and conserver of historical streetscapes, and of physical memories of the past. Civil society groups are diverse and represent different 
positions (Tsujinaka 2003; Pekkanen 2006; Sorensen 2006). Some, especially those advocating development projects, tend to be closer to government than others. Nevertheless, it is undoubtedly the case that, in a national context, a great number of conservation efforts have been planned and led by private citizens working with groups of like-minded individuals, as in the examples introduced above. In some cases these individuals are office-holders in local government, but are acting in a more or less private capacity (Waley 2005a). In Tokyo, where the development pressures tend to be overwhelming, it calls for great skill, energy and enthusiasm to be able to lead a successful campaign for the conservation of a historic structure. And it needs emphasising here that at the heart of the issues surrounding conservation in Tokyo lie a considerable number of disincentives. One of these is the strong constitutional position of the property owner, which has encouraged a sense of empowerment to rebuild in line with household circumstances (Sorensen 2011). Another is the permissive planning regime, which in most urban zones allows for the construction of taller buildings than those that are being replaced. A third is pressure to construct with fire-proof materials, clearly an important consideration. Finally, there is the pressure imposed by the inconvenience (damp, lack of insulation against heat loss and noise, and possible vermin infestation) of old houses. The conservation of old houses in Tokyo (as elsewhere in Japan) is therefore problematic for a number of reasons. Any civil society action has to tackle strongly entrenched social and cultural forces.

\section{Commodification of the Past in Images, Objects and Place}

Commodification of place is omnipresent. So long as property retains an exchange value, then it is inevitable that place will be used to boost value. This is, after all, one of the principal mechanisms behind the process of gentrification. In Tokyo too, this mechanism is at work, but perhaps less than in some other cities as there is less residential segregation and a smaller disparity between affluent parts of the city and poorer areas. Commodification of place is often related to the past, to the heritage and (imagined) history of a city district. In many major cities of the world, especially but not only in Europe, age and a sense of history, adds to the value of property in a place. Tourism is an important generator of place commodification, as I noted earlier in the case of Paris. The same point could be made of many other leading world cities, but not Tokyo, where tourism plays a lesser part in the commodification of the past.

Commodification of place in Tokyo works in slightly different ways. It is first of all a commodification that is built around place names, place names (as elsewhere with street names) that evoke memories and that radiate various meanings and connotations. It is attached too to consumption practices, and especially to drinking and eating. Here, however, an important point of reference, as noted earlier with buildings and the general sense of urbanism, is with the foreign, often cast as exotic. Cities throughout the world have Italian restaurants and British or Irish pubs, for example, but where else can you find, as you can in Tokyo, a Venetian enoteca or a bar specialising in whiskies from the Scottish island of Islay? The range and extent of the embrace of foreign practices in the preparation and consumption of food and drink is surely without parallel.

Commodification of place is one form of commodification of the past, but this takes a number of different forms: in museums, through media such as television drama series, through products for visitors and tourists, and through the re $^{-}$creation of past landscapes and experiences. Here I will pick up on two of these, before looking in more detail at the commodification of Shitamachi 
as Tokyo's past — and the commodification of the past in Shitamachi.

The commodification of the past in museums reached its peak in the 1980s, the decade of supreme national confidence, continuing into the 1990s, when Japan's economic power, already in relative decline, shifted over into the cultural domain and was reflected in a re-imagination of aspects of the country's history. At a political level, one of the key measures was prime minister Takeshita Noboru's Hometown Revitalisation Initiative, under which all local government entities regardless of size received $¥ 100$ million to spend as they pleased. Many chose to construct museums, later criticised by some as empty shells. In Tokyo a much grander project was underway, the construction of a museum to celebrate the entire history of the city, the Edo Tokyo Hakubutsukan, built to mark the 400th anniversary of the founding of Edo Tokyo (Sand 2001; Iwatake 2003). Referred to by Jordan Sand as a project that "monumentaliz [es] the everyday" $(2001,392)$, the museum uses commodities to transmit a sense of the city's past, and commodifies the past in a series of objects at a variety of scales.

In recent years, a new form of commodification of the past has appeared in the streets of the city, something that might best be seen as commodification in and of the streets themselves. Thus, a replica of the original Shinbashi station, the city's first railway station, has been built not far from its original location, while in nearby Marunouchi, one of the red-brick buildings of the "London Block" (Itchō Rondon, built in the 1890s to resemble streets in the British capital) has been carefully re-constructed to house a museum, the Mitsubishi Ichigōkan Gallery. Meanwhile, in Shinjuku a short stretch of road has been converted into a $1960 \mathrm{~s}^{-}$style retro ambience, almost like a stage set. In Ebisu, a back alley near the station has been spruced up in order to resemble a sort of indeterminate past, one which many of its habitués will remember from their youth (Swinnerton 2008).

Perhaps the best example of place as commodification of Tokyo's past is offered by Shitamachi. I have written elsewhere in detail about the diverse meanings of Shitamachi (Waley 2002). Here I wish to stress Shitamachi's role as a repository of Tokyo's past and as a conduit for its commodification. As elsewhere in the city, but more so in Shitamachi, this occurs in various ways: through the media, through consumption practices and experiences, through commodities (souvenirs, harking back to the derivation of the word in French, 'to remember') which incorporate patterns, stories, people associated with Shitamachi.

Commodification of a certain vision of Shitamachi is a pronounced feature of media representations, the most famous example of which is provided by the Tora-san films. Set in a distant eastern suburb that would not have been considered part of Shitamachi until very recently, the Tora ${ }^{-}$san films are imbued with a sense of the past "being a better place" and with the values that are thought in the popular imagination to represent that past (Satō 1988). These are the values and the lifestyles associated by many with Shitamachi. Other somewhat rosetinted views of Shitamachi and the way of life associated with the area can be found in various television soaps and dramas.

As elsewhere in the city, if not more so, the past in Shitamachi is commodified through food. In Tsukishima, in central Tokyo (Chūo Ward) but still within the fuzzy borders of Shitamachi, there are said to be over one-hundred restaurants serving the traditional, very rough-and-ready dish known as monja-yaki, a gelatinous pancake fried on a hot plate and associated with an earlier era of simple living. In Asakusa, in Kōen-dōri, on the west side of the Kannon temple, the predominantly Korean bar owners have through the fairly straightforward expedient of placing tables and chairs outside their premises created a lively sense of Tokyo in the not-too-distant 
past. Whether this happened by design or whether it was a strategy is open to question, but the result is a successful reinvention and commodification of urban collective memory (Waley 2006). Indeed, Asakusa, at the centre of Shitamachi, has had successive waves of retro-fit, its streets and shop fronts $\mathrm{re}^{-}$clad in historical "costume", one of the most deeply commodified landscapes in the city.

\section{Conclusion: The Past Made Distant and the Exotic Brought Close}

I started this paper with a reflection on the malleable nature of Tokyo's physical environment, built and re-built, shaped and re-shaped, torn down and re-fashioned, building by building, sometimes block by block, and occasionally on a larger scale. As I hope I have shown this malleability denies the pretence of permanence and invites the manipulation of memory. This in turn creates an instability in the narrative that surrounds historical events, mitigating against state-initiated projects designed to plant a commemorative monument in the urban landscape. Instead, the past is remembered in improvised ways, in small spaces and often on private initiative - not collective memory but private memory rendered collective (Veldkamp 2005).

I have sought to argue in this paper that Tokyo's malleable urban landscape encourages a commodification of the past through the manipulation of memory, memory that is then transferred onto place. This can be seen in the popularity of all things connected with Edo that characterised the last decades of the twentieth century in particular. The many-faceted use of Edo as "historical imaginary" has been well portrayed by Carol Gluck (1998, 262). "Like the heritage industry in Britain," she writes, "Edo figured prominently in commodified nostalgia" $(1998,264)$. But this use of the historical imaginary is not confined to the distant past. The past as recent memory has also been translated into the contemporary urban landscape. As Ching (2000) and Iwabuchi (2002) have argued, this represents a nostalgia for a youthful Japan and a simpler life with its moral certitudes. This vision of a time when people were better off because they were worse off has anchored itself in the urban environment in a number of specific ways, through, for example, the retro re-fashioning of the streetscape in Shinjuku, Ebisu and some other parts of the city.

It used to be said of Tokyoites that they had no furusato, no "other place," no hometown. But I have suggested here that in some ways Shitamachi, an idealised space - and time - in which values were upheld and life was simpler, serves as a furusato for all Japanese, including Tokyoites (Robertson 1998). And it has been, as a consequence, commercialised and commodified both in particular locations, for example those associated with Tora-san, and in consumable products such as monjayaki. But this idealisation - and commodification - of the past is not restricted to Tokyo. The past for many Japanese of the baby boom generation is rural; their furusato is an idealised rural society (Ehrentraut 1993). Throughout the country, the past has been wrapped up, thematically presented and re-packaged as commodity, often in the form of a theme park. In some places that past has been collected and moved off to somewhere "distant," and in the process, it has been commodified, a classic example being that of Meiji Mura (Herrington 2008). Similarly, distant places have been moved into Japan, and commodified in the process. Tokyo Disneyland and DisneySea alongside it, with its mock-up of Venice and its Mediterranean harbour, are perfect exemplars of this taste for a commodified exotic location brought within arm's reach, but there are a number of others including a Provençal village in Tama New Town and various imitation Italian streets. 
I have argued in this paper that Tokyo's urban landscape lacks reminders of its history, and I have sought to explain why. But as a sort of coda, it seems worth wondering whether it matters; perhaps this lacuna is less significant than it might otherwise be. And this above all else because two tendencies predominate. The first is a readiness to celebrate the past through events such as festivals and gatherings of all sorts. The second is a pronounced sense of the ephemeral nature of the built environment engendered both by the susceptibility to fire and lack of durability of traditional building materials and by the tremendous pressures in favour of development that result from the extreme commodification of the urban terrain (land and buildings). The two factors are of course not unrelated. And this has led to a tendency to mourn rather than commemorate that which has disappeared.

\section{References}

Atkinson, D., and D. Cosgrove (1998) Urban rhetoric and embodied identities: city, nation, and empire at the Vittorio Emanuele II monument in Rome, 1870-1945. Annals of the Association of American Geographers 88 : 28-49.

Azaryahu, M. (2003) RePlacing Memory: the reorientation of Buchenwald. Cultural Geographies 10 : 1-20.

Ben-Ari, E. (2005) Coincident events of remembrance, coexisting spaces of memory: the annual memorial rites at Yasukuni Shrine. In Perspectives on Social Memory in Japan, eds. T. Y. Hui, J. van Bremen and E. Ben-Ari, 7593. Folkestone: Global Oriental.

Bosworth, R. (2011) Whispering City: Rome and its Histories. New Haven, R. I.: Yale University Press.

Brumann, C., and R. Cox. (2011) Making Japanese Heritage. London: Routledge.

Cartier, C. (2002) Transnational urbanism in the reform ${ }^{-}$era Chinese city: Landscapes from Shenzhen. Urban Studies $39: 1513-1532$.

Chang, T., and B. Yeoh (1999) New Asia - Singapore: communicating local cultures through global tourism. Geoforum $30: 101-115$.

Chao, E. (2003) Dangerous work: women in traffic. Modern China $29: 71-107$.

Charlesworth, A. (1994) Contesting places of memory: the case of Auschwitz. Society and Space $12: 579-593$.

Ching, L. (2000) Globalizing the regional, regionalizing the global: mass culture and Asianism in the age of late capital. Public Culture $12: 233-57$.

Coser, L. (1992) Introduction: Maurice Halbwachs 1877-1945. In M. Halbwachs. On Collective Memory. Edited, translated and with an introduction by L. Coser. Chicago: University of Chicago Press, pp. 1-36.

Duteurtre, B. (2011) The Paris of our dreams. Le Monde Diplomatique English edition. September, p. 16.

Ehrentraut, A. (1993) Heritage authenticity and domestic tourism in Japan. Annals of Tourism Research $20: 262-278$.

Fujimori, T. (1982) Meiji no Tōkyō keikaku (Meiji plans for Tokyo), Tokyo: Iwanami Shoten.

Gluck, C. (1998) The invention of Edo. In Mirror of Modernity: Invented Traditions of Modern Japan, ed. S. Vlastos, 262-284. Berkeley, Ca: University of California Press.

Herrington, S. (2008) Meiji-mura, Japan: negotiating time, politics, and location. Landscape Research 33 : 407-423.

Hohn, U. (1997) Townscape preservation in Japanese urban planning. Town Planning Review 68 : 213-255.

Iwabuchi, K. (2002) Recentering Globalization: Popular Culture and Japanese Transnationalism. Durham: Duke University Press.

Iwatake, M. (2003) From a Shogunal City to a Life City: Tokyo between Two Fin-de-Siècles. In N. Fiévé and P. Waley (eds). Japanese Capitals in Historical Perspective: Place, Power and Memory in Kyoto, Edo and Tokyo. London: RoutledgeCurzon, 223-256.

Jinnai, H. (1985) Tōkyō no kūkan jinruigaku (The Anthropology of Space in Tokyo). Tokyo: Chikuma Shobō.

Johnson, N. (1995) Cast in stone: monuments, geography and nationalism. Society and Space $13: 51^{-65}$.

Jones, O. (2005) An ecology of emotion, memory, self and landscape. In Emotional Geographies, eds. J. Davidson, L. Bondi, and M. Smith, 205-218. Aldershot: Ashgate.

Karacas, C. (2010) Place, public memory, and the Tokyo air raids. Geographical Review $100: 521-537$.

Kong, L., and B. Yeoh (2003) The Politics of Landscapes in Singapore: Constructions of 'Nation. Syracuse: Syracuse University Press.

Kusno, A. (2004) Whither nationalist urbanism ? Public life in Governor Sutiyoso's Jakarta. Urban Studies 41 : 23772394.

Leitner, H., and P. Kang (1999) Contested urban landscapes of nationalism: the case of Taipei. Cultural Geographies $6: 214^{-}-233$.

Logan, W. ed. (2002) The Disappearing 'Asian' City: Protecting Asia's Urban Heritage in a Globalizing World. Oxford: 
Oxford University Press.

Lowenthal, D. (1985) The Past Is a Foreign Country. Cambridge: Cambridge University Press.

Maeda, A. (1982) Toshi kūkan no naka no bungaku (Literature in urban space), Tokyo: Chikuma Shobō.

Miyauchi, S. (1990) The direction and problems of the underground car park plan (Chika chushajō keikaku no dōkō to mondaiten). In Shinobazu pond: waterside space in the heart of the city (Shinobazu ike: toshin no mizube $k \bar{u} k a n$ ), ed. Shinobazu Ike Chika Chushajō Mondai o Kangaeru Tsudoi Jikkō Iinkai (Executive committee of the assembly to consider the problem of the Shinobazu Pond Underground Car Park), 14-17, Tokyo: Shinobazu Pond Executive Committee.

Mori, M. (2003) Tokyo's heritage: from conservation to resuscitation and use (Tōkyō isan: hozon kara saisei, katsuyō e). Tokyo: Iwanami Shoten.

Nora, P. (1989) Between memory and history. Representations $26: 7-24$.

Nunokawa, H. (2007) Machizukuri and historical awareness in the old town of Kobe. In Living Cities in Japan: Citizens' Movements, Machizukuri and Local Environments in Japan, ed. A. Sorensen and C. Funck, 172-185, London: Routledge Curzon.

Ogawa, K. (1990) The value of the Shinobazu Pond environment and the importance of its preservation (Shinobazu ike no kankyō no kachi to hozen no jūyōsei). In Shinobazu pond: waterside space in the heart of the city (Shinobazu ike: toshin no mizube kūkan), ed. Shinobazu Ike Chika Chushajō Mondai o Kangaeru Tsudoi Jikkō Iinkai (Executive committee of the assembly to consider the problem of the Shinobazu Pond Underground Car Park), 2-13, Tokyo: Shinobazu Pond Executive Committee.

Pekkanen, R. (2006) Japan's dual civil society: members without advocates. Stanford, Ca: Stanford University Press.

Purvis, M., and D. Atkinson (2009) Performing wartime memories: ceremony as contest at the Risiera di San Sabba death camp, Trieste. Social \& Cultural Geography $10: 337-356$.

Robertson, J (1998) It takes a village: internationalization and nostalgia in postwar Japan. In Mirror of Modernity: Invented Traditions of Modern Japan, ed. S. Vlastos, Berkeley, Ca: University of California Press, 110-131.

Sand, J. (2001) Monumentalizing the everyday: The Edo-Tokyo Museum. Critical Asian Studies 33 :351-378.

Satō, T. (1988) Tōkyō to iu shuyaku: eiga no naka no Edo-Tōkyō (Tokyo as Lead Role: Edo-Tokyo in Films). Tokyo: Kōdansha.

Seaton, P. (2007) Japan's Contested War Memories: The 'Memory Rifts' In Historical Consciousness of World War II. London: Routledge.

Shimizu, H. (1998) Ten years of the 'Love Shinobazu Pond Group' linking through to the 21st century' (Nijū isseki e tsunagu "Shinobazu ike o aisuru kai" no 10 nen). In The current state of the underground car park issue: looking back over the ten years of the Love Shinobazu Pond Group (Chika chūshajō mondai no ima: Shinobazu ike o aisuru kai no 10 nen o furikaette), ed. Shinobazu Ike o Aisuru Kai (Love Shinobazu Pond Group), 2-3, Tokyo.

Simon, S. (2003) Contesting Formosa: Tragic Remembrance, Urban Space, and National Identity in Taipak. Identities: Global Studies in Culture and Power $10: 109-131$.

Sorensen, A. (2006) Centralization, urban planning, governance, and citizen participation in Japan. In Cities, Autonomy, and Decentralization in Japan, eds. C. Hein and P. Pelletier, 101-127, London: Routledge.

Sorensen, A. (2011) Evolving property rights in Japan: patterns and logics of change. Urban Studies 48:471-491.

Steele, W. (1990) Edo in 1868: the view from below. Monumenta Nipponica $45: 127-155$.

Steelman, T. (2011) Education, commemoration, reflection: an exploration of 'Parcom' and its use in struggles for social justice. MA Dissertation, Masters in Activism and Social Change, School of Geography, University of Leeds.

Swinnerton, R. (2008) Bright lights, retro style 2008. Japan Times 21 November. http://search.japantimes.co.jp/cgibin/fg20081121rs. html

Takahashi, T. (2006) The national politics of the Yasukuni Shrine. Translated by P. Seaton. In Nationalisms in Japan, ed. N. Shimazu, 155-180, London: Routledge.

Tan, $\mathrm{H}^{-} \mathrm{J}$., and P. Waley (2006) Planning through procrastination: The preservation of Taipei's cultural heritage. Town Planning Review 77 :531-555.

Till, K. (1999) Staging the past: landscape designs, cultural identity and Erinnerungspolitik at Berlin's Neue Wache. Cultural Geographies $6: 251-283$.

Till, K. (2003) Places of memory. In Companion to Political Geography, ed. J. Agnew, K. Mitchell, and G. O' 'Tuathail, 289-301, Oxford: Blackwell.

Tsujinaka, Y. (2003) From developmentalism to maturity: Japan's civil society organizations in comparative perspective. In The State of Civil Society in Japan, eds. F. Schwartz and S. Pharr, 83-115, Cambridge: Cambridge University Press.

Veldkamp, E. (2005) Memorializing and remembering animals in Japan. In Perspectives on Social Memory in Japan, eds. T. Y. Hui, J. van Bremen and E. Ben-Ari, 58-74, Folkestone: Global Oriental. 
Vlastos, S., ed. (1998) Mirror of Modernity: Invented Traditions of Modern Japan. Berkeley, Ca: University of California Press.

Waley, P. (1991) Tokyo: City of Stories. New York: Weatherhill.

Waley, P. (1996) On the far bank of the river: places of recreation on the periphery of Japan's pre-modern cities. Ecumene $3: 384-407$.

Waley, P. (2002) Moving the margins of Tokyo. Urban Studies $39: 1533-1550$.

Waley, P. (2003) By ferry to factory: crossing Tokyo's Great River into a new world. In Japanese Capitals in Historical Perspective: Place, Power and Memory in Kyoto, Edo and Tokyo, eds. N. Fiévé and P. Waley, 208-232, London: Routledge Curzon.

Waley, P. (2005a) Ruining and restoring rivers: the state and civil society in Japan. Pacific Affairs 78:195-215.

Waley, P. (2005b) Parks and landmarks: planning the Eastern Capital along western lines. Journal of Historical Geography $31: 1-16$.

Waley, P. (2006) Re-scripting the city: Tokyo from ugly duckling to cool cat. Japan Forum $18: 361-381$.

Waley, P. (2010) From flowers to factories: a peregrination through changing landscapes on the edge of Tokyo. Japan Forum 22 :281-306.

Waley, P. (forthcoming) Who cares about the past in today's Tokyo ? In Urban Spaces in Japan : Cultural and Social Perspectives, eds. E. Schulz and C. Brumann, London: Routledge.

White, J. (2011) Mirrors of Memory: Culture, Politics, and Time in Paris and Tokyo. Charlottesville, Va: University of Virginia Press. 